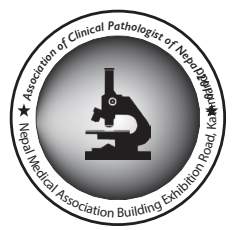

\title{
A comparison of two techniques of cell block preparation
}

\author{
Anita Kasichhwa ${ }^{1}$, Shreya Shrivastav $^{2}$, Ayushi Agrawal ${ }^{3}$ \\ ${ }^{I}$ Department of Histotechnology, Institute of Medicine, Tribhuwan University Teaching Hospital, Kathmandu, Nepal. \\ ${ }^{2}$ Department of Pathology, Institute of Medicine, Tribhuwan University Teaching Hospital, Kathmandu, Nepal. \\ ${ }^{3}$ John Snow India Pvt. Ltd., New Delhi, India
}

\author{
Keywords: \\ Cell block; \\ Collodion bag; \\ FNAC; \\ Plasma-thromboplastin;
}

\begin{abstract}
Background: Cell block technique is a method of preparing cytological material so that it can be processed, sectioned, stained, and viewed as a histology section. The study compared two methods of cell block preparation, plasma-thromboplastin method and collodion bag technique of cell block preparation.

Materials and Methods: Samples were randomly processed by plasma-thromboplastin technique or by collodion bag technique. Hematoxylin/Eosin stained cell block sections were examined and scored scaling from 1 to 3 for cellularity, clarity, nuclear features, cytoplasm, use of ancillary test and recovery of cell-cluster and fragments. Mann-Whitney $U$ test was used for comparing two methods and establishing statistical significance.
\end{abstract}

Results: The median cellularity score was 2.0 for plasma-thromboplastin and 1.0 for collodion bag. The median morphological preservation score and use of ancillary test score were 2.0 for both of the method while median score for recovery of cell cluster and fragments was 2.0 for collodion bag and 1.0 for plasma-thromboplastin. Statistically, both of the methods had similar results in cell block quality.

The median total score for plasma-thromboplastin and collodion bag were 10.0 and 11.0 respectively. Diagnostic cell blocks were obtained in $46.51 \%$ of cell block by plasma-thromboplastin method and $60.52 \%$ of cell block by collodion bag method improving the diagnosis over conventional smear in $76.74 \%$ and $81.57 \%$ respectively.

Conclusion: Cell block by plasma-thromboplastin and collodion bag method are cost effective, useful adjunct to FNA for diagnosis of mass lesion. Both techniques has no significant difference in quality of cell block produced.

\section{Correspondence:}

Dr. Shreya Shrivastav, $M D$

Department of pathology, Institute of Medicine, Tribhuwan University Teaching Hospital, Kathmandu, Nepal.

ORCID ID: 0000-0002-6357-6387

Email: shreya_shrivastav@hotmail.com

Reveived : February $7^{\text {th }} 2018$; Accepted : March14 $4^{\text {th }} 2019$; Published : March $29^{\text {th }} 2019$

Citation: Kasichhwa A, Shrivastav A, Agrawal A. A comparison of two techniques of cell block preparation. J Pathol Nep 2019;9:1469-74. DOI 10.3126/jpn.v9i1.23370

Copyright: This is an open-access article distributed under the terms of the Creative Commons Attribution 4.0 International License, which permits unrestricted use, distribution, and reproduction in any medium, provided the original author and source are credited.

\section{INTRODUCTION}

Fine-Needle aspiration cytology (FNAC) is a simple, inexpensive, atraumatic and safe cytodiagnostic technique for obtaining a tissue diagnosis of subcutaneous and other tumors. It is valuable for preoperative assessment of lesions of the breast, thyroid, lymph nodes, liver, lungs, skin, soft tissues and bones with the aid of fine needle under negative pressure. Modern imaging techniques enable the method to be extended to virtually any part of the body, including deep anatomic sites, making it an increasingly common procedure, providing rapid and safe diagnosis. FNAC is a reliable method to distinguish benign from malignant 
lesion, and to classify neoplasms and other pathologic processes. ${ }^{1-4}$ FNAC material may be analyzed with conventional smear (direct smear method), liquid-based cytology and preparation of cell block (CB), of which the latter two can further aid in the cytopathological diagnosis, facilitating ancillary studies. ${ }^{5,6}$ Sometimes FNA does not yield sufficient information for precise diagnosis and the risk of false negative or indeterminate diagnosis exists. In order to overcome these problems, cell block technique has been resorted to make the best use of available material. ${ }^{7}$

Various CB techniques have been developed over the years that vary in scope and the type of fixatives, processing, and embedding techniques used. Some of the most common techniques include cell blocks from tissue fragments by plasma thromboplastin method, Bacterial Agar Method, HistoGel, inverted filter sedimentation, simple sedimentation, collodion bag technique and Cellient-TM Automated Cell Block System. ${ }^{8,9}$ Hence, the present study is done to compare two different methods of cell block, plasma thromboplastin(PT) method and collodion bag (ColB) method for cytopathologic diagnosis of FNA.

\section{MATERIALS AND METHODS}

A prospective study was conducted in Department of Pathology and Department of Radiology, Tribhuvan University Teaching Hospital (TUTH), Kathmandu from April to September 2017 after taking permission from Institutional Review Board of Institute Of Medicine.

Samples of FNAC material from patients undergoing FNAC in Histocytopathology department and patient undergoing USG-guided FNAC, Radiology department were used. Aspirate obtained from FNAC was used for conventional smear preparation and the remaining portion was rinsed in $10 \%$ neutral buffered formalin and cell block was made either with PT technique or ColB technique. A total of 33 cases that underwent FNAC had a cell block made by PT technique while 31 site matched cases had a cell block made by ColB technique.

For plasma PT method, the FNA needle was rinsed in $10 \%$ neutral buffered formalin and stored in $15 \mathrm{ml}$ Falcon tube. The sample was centrifuged for 10 minutes at $2500 \mathrm{rpm}$ and the supernatant fluid was discarded, $0.5 \mathrm{~mL}$ of plasma and 2 drops of thrombin(Thrombin, 5000 units, topical, 1 vial: Add $10 \mathrm{ml}$ of distilled water) was added, and the sample was quickly agitated. A clot formed within 30 to 60 seconds. The clot was then placed in a tissue cassette lined with filter paper, which was then placed in a formalin container and processed as a routine histology sample.

For ColB technique, Collodion bags ("cell-bags") was prepared by pouring the collodion solution to the top of polypropylene plastic or pyrex conical centrifuge tubes. The Collodion was then recovered and the tubes left upside down for a short time. A thin film of collodion, about 20$50 \mu \mathrm{m}$ thick, remained over the inner surface of the tubes, which was then filled with distilled water and stoppered with paraffin membrane and stored in refrigerator. This hardened the collodion and prevented excessive drying of the film. Immediately before use, distilled water was discarded and the FNA needle rinsed material suspended in 10\% neutral buffer formalin was poured inside the tubes, which was then stoppered and centrifuged for 10 minutes at $2500 \mathrm{rpm}$. The clear supernatant was discarded. The Collodion Bag, with the sediment at its bottom, was gently extracted with a finger or forceps. A cotton string was tied around the bag, thereby trapping the pellet at the base of the bag. The bag was then placed sideways on the bench and cut just above the string and placed in cassette with label. The cassette was transferred to a container of $10 \%$ buffered formalin and processed as per routine histology.

Conventional smears (CS) were stained with Giemsa stain as well as Papanicolaou stain while cellblock (CB) sections obtained from either PT technique or ColB technique were stained with Hematoxylin and Eosin stain. CS and $\mathrm{CB}$ sections were compared with using following scoring criteria enlisted in table 1 . The slides were scored on scale of 1 (poor) to 3 (good) for the following criteria: cellularity, morphology, use of ancillary test and recovery of cell cluster and fragments, as described table 1. Based on the given criteria a minimum score of 6 and a maximum score of 18 was given to each cell block. A diagnostic CS was defined as a case in which the conventional smears of FNA material was sufficient to make a diagnosis while a diagnostic $\mathrm{CB}$ was a cell block in which the material was either as good or better than the material on the conventional smears. If no diagnostic material was obtained on conventional smear or cell block, then the case was excluded from the study.

Data were entered and analyzed using Statistical Package for Social Sciences (SPSS), windows version 15. Descriptive analysis was performed and Mann-Whitney U test was used for comparing the median scores of the two methods and establishing statistical significance.

\section{RESULTS}

The present study included 64 patients, 19 males and 45 females, with various mass lesions on lymph node, breast, thyroid, parotid swelling and USG-guided intra-abdominal masses, such as liver masses, pancreatic mass and lung mass. The study population comprised of people from the age 2 years to 74 years. In both of the method, the majority of patients were presented in the $5^{\text {th }}$ decade $(22.2 \%)$ followed by the 4 th decade $(19.0 \%)$.

Site-wise distribution and diagnosis made by cell block obtained by PT technique and ColB technique were shown in Table 2 and Table 3 respectively. 
Table 1: Scoring Criteria for evaluation of cell block

\begin{tabular}{|c|c|c|c|}
\hline Criteria & Score 1 & Score 2 & Score 3 \\
\hline Cellularity & Paucicellular (rare cells) & $\begin{array}{l}\text { Moderately cellular } \\
\text { (numerous cells) }\end{array}$ & $\begin{array}{l}\text { Abundantly cellular } \\
\text { (numerous cells and clusters) }\end{array}$ \\
\hline $\begin{array}{l}\text { Morphology } \\
\text { - Clarity }\end{array}$ & Poor & Fair & Good \\
\hline - Nuclear features & $\begin{array}{l}\text { Nuclear contours indistinct } \\
\text { Chromatin not preserved } \\
\text { Nucleoli not apparent } \\
\text { Mitotic figures not identified }\end{array}$ & $\begin{array}{l}\text { Some nuclear contours visible } \\
\text { Chromatin partially preserved } \\
\text { Some nucleoli visible } \\
\text { Few identifiable mitotic figures }\end{array}$ & $\begin{array}{l}\text { Distinct nuclear contours } \\
\text { Distinct chromatin pattern } \\
\text { Prominent nucleoli } \\
\text { Mitotic figures readily identified }\end{array}$ \\
\hline - Cytoplasm & $\begin{array}{l}\text { No vacuoles/granules } \\
\text { No cell boundaries }\end{array}$ & $\begin{array}{l}\text { Some vacuoles/granules } \\
\text { Some cell boundaries }\end{array}$ & $\begin{array}{l}\text { Cytoplasmic vacuoles/granules } \\
\text { evident } \\
\text { Distinct membrane boundaries }\end{array}$ \\
\hline Use of ancillary tests & Not suitable for use & Not done & Done \\
\hline
\end{tabular}

Table 2: Site-wise diagnosis by PT technique

\begin{tabular}{|c|c|c|c|c|}
\hline Site & & Diagnosis & Cell block diagnosed case & Case \\
\hline \multirow{4}{*}{ Breast } & & Fibroadenoma & 2 & \multirow{4}{*}{6} \\
\hline & & Fibrocystic changes & 1 & \\
\hline & & Mastitis & 2 & \\
\hline & & $\begin{array}{l}\text { Inadequate diagnostic } \\
\text { material on cell block }\end{array}$ & 1 & \\
\hline \multirow{5}{*}{\multicolumn{2}{|c|}{ Lymph node }} & $\begin{array}{l}\text { Metastatic small cell } \\
\text { carcinoma }\end{array}$ & 1 & \multirow{5}{*}{10} \\
\hline & & Benign cyst & 0 & \\
\hline & & Reactive lymph node & 3 & \\
\hline & & Tubercular lymphadenitis & 1 & \\
\hline & & $\begin{array}{l}\text { Inadequate diagnostic } \\
\text { material on cell block }\end{array}$ & 5 & \\
\hline \multirow{4}{*}{ Intraabdominal masses } & \multirow{3}{*}{ Liver mass } & $\begin{array}{l}\text { Metastatic small cell } \\
\text { carcinoma }\end{array}$ & 1 & \multirow{3}{*}{4} \\
\hline & & Non-small cell carcinoma & 1 & \\
\hline & & $\begin{array}{l}\text { Inadequate diagnostic } \\
\text { material on cell block }\end{array}$ & 2 & \\
\hline & Pancreatic mass & Pancreatoblastoma & 1 & 1 \\
\hline Lung mass & & Adenocarcinoma & 1 & 1 \\
\hline \multirow{2}{*}{\multicolumn{2}{|c|}{ Parotid }} & Pleomorphic adenoma & 1 & \multirow[b]{2}{*}{2} \\
\hline & & $\begin{array}{l}\text { Inadequate diagnostic } \\
\text { material on cell block }\end{array}$ & 1 & \\
\hline \multirow{4}{*}{ Thyroid } & & Autoimmune thyroiditis & 1 & \multirow{4}{*}{9} \\
\hline & & Colloid goiter & 1 & \\
\hline & & Papillary cell carcinoma & 2 & \\
\hline & & $\begin{array}{l}\text { Inadequate diagnostic } \\
\text { material on cell block }\end{array}$ & 5 & \\
\hline Total & & & & 33 \\
\hline
\end{tabular}

In our study, histochemical stain such as Zeihl Neelsen stain and Periodic acid Schiff's stain were performed in one case which was necrotizing lymphadenitis diagnosed by ColB technique. Also immunohistochemistry (IHC) was done in CB by PT technique in a case of pancreatoblastoma, which was found to be Solid Pseudopapillary Epithelial Neoplasm on excision of the pancreatic mass. Nine cases in which cell block was performed by PT method and 8 cases in which cell block was performed by ColB were suitable for IHC. 
Table 3: Site-wise diagnosis by ColB technique

\begin{tabular}{|c|c|c|c|c|}
\hline Site & & Diagnosis & Cell block diagnosed case & Case (n) \\
\hline \multirow{3}{*}{ Breast } & & Fibroadenoma & 1 & \multirow{3}{*}{7} \\
\hline & & $\begin{array}{l}\text { Metastatic ductal } \\
\text { carcinoma }\end{array}$ & 2 & \\
\hline & & $\begin{array}{l}\text { Inadequate diagnostic } \\
\text { material on cell block }\end{array}$ & 4 & \\
\hline \multirow{7}{*}{\multicolumn{2}{|c|}{ Lymph node }} & $\begin{array}{l}\text { Granulomatous inflam- } \\
\text { mation }\end{array}$ & 1 & \multirow{7}{*}{13} \\
\hline & & Metastatic adenocarcinoma & 1 & \\
\hline & & $\begin{array}{l}\text { Metastatic ductal } \\
\text { carcinoma }\end{array}$ & 1 & \\
\hline & & Necrotizing lymphadenitis & 3 & \\
\hline & & Reactive lymph node & 3 & \\
\hline & & Tubercular lymphadenitis & 3 & \\
\hline & & $\begin{array}{l}\text { Inadequate diagnostic } \\
\text { material on cell block }\end{array}$ & 1 & \\
\hline \multirow{3}{*}{ Intraabdominal masses } & Liver mass & Adenocarcinoma & 2 & \multirow{3}{*}{3} \\
\hline & \multirow{2}{*}{ Pancreatic mass } & $\begin{array}{l}\text { Better columnar cells } \\
\text { present than CS }\end{array}$ & 1 & \\
\hline & & $\begin{array}{l}\text { Inadequate diagnostic } \\
\text { material on cell block }\end{array}$ & 0 & \\
\hline \multirow[b]{2}{*}{ Parotid } & & Pleomorphic adenoma & 1 & \multirow[b]{2}{*}{2} \\
\hline & & $\begin{array}{l}\text { Inadequate diagnostic } \\
\text { material on cell block }\end{array}$ & 1 & \\
\hline \multirow{3}{*}{ Thyroid } & & Autoimmune thyroiditis & 3 & \multirow{3}{*}{6} \\
\hline & & Colloid goiter & 3 & \\
\hline & & $\begin{array}{l}\text { Inadequate diagnostic } \\
\text { material on cell block }\end{array}$ & 0 & \\
\hline Total & & & & 31 \\
\hline
\end{tabular}

Table 4: Median score of both cell block techniques

\begin{tabular}{lccc}
\hline Criteria & & $\begin{array}{c}\text { PT technique } \\
\text { (median score) }\end{array}$ & $\begin{array}{c}\text { ColB technique } \\
\text { (median score) }\end{array}$ \\
\hline Cellularity & Clarity & 2 & 1 \\
Morphology & Nuclear features & 2 & 2 \\
& Cytoplasm & 2 & 2 \\
Use of ancillary tests & & 1 & 2 \\
Recovery of cell clusters and fragments & 2 & 2 \\
\hline Total score & 1 & 2 \\
\hline
\end{tabular}

Table 5: Comparision of the number of diagnostic CSs and diagnostic CBs with other studies.

\begin{tabular}{lllccc}
\hline S.N. & \multicolumn{1}{c}{ Study } & Diagnostic FNA & Diagnostic CB & Diagnostic FNA+CB \\
\hline $\mathbf{1}$ & & Nathan et al.(35-11) & $84.8 \%$ & $73.3 \%$ & $100 \%$ \\
$\mathbf{2}$ & & Vinayakmurthy et al.(14-10) & $96.96 \%$ & $68.18 \%$ & $100 \%$ \\
\\
\multirow{3}{*}{$\begin{array}{l}\text { Present } \\
\text { study }\end{array}$} & PT technique & ColB technique & $74.41 \%$ & $46.51 \%$ & $76.74 \%$ \\
& & & $78.94 \%$ & $60.52 \%$ & $81.57 \%$
\end{tabular}


Among the various features of cell block that were scored, the median score for morphology and use of ancillary test were equal for both of cell block techniques. (Table 4) On comparison of total score for the two methods, median score for Col B was 11 and for PT was 10, which was not significantly different. Therefore it was found that the two methods of cell block preparation were not significantly different from one another. When conventional smear technique was combined with PT technique, diagnostic yield was $76.74 \%$ in comparison to conventional smear technique combined with ColB technique (81.57\%).

\section{DISCUSSION}

FNA cytology has been established as the first line of investigation of mass lesions in different organs and sites. FNA of space occupying lesions in superficial or deep anatomic sites is an increasingly common procedure, providing rapid and safe diagnosis. In adjunct to smears, CB preparations can be used as a complimentary tool for cytological diagnosis. ${ }^{10}$

The main advantage of cell block is that it aids in cytopathological diagnosis by facilitating ancillary studies. In our study, histochemical stain such as AFB stain and PAS stain were performed in two cases. Also IHC was done in one case. Nine cases in which cell block was performed by PT method and 8 cases in which cell block was performed by ColB were suitable for IHC. However, they were not performed due to availability of better tissue in the form of biopsy. Other reasons were the limited availability of ancillary tests in our setting and patients being lost to follow up. One case of pancreatoblastoma was diagnosed on FNAC; the cell block was sent for IHC to another center but it was reported inadequate.

In our study, diagnostic material was obtained in 20(46.51\%) of 43 cell block by PT method while CS showed diagnostic material in $32(74.41 \%)$ of these cases. Diagnostic material was obtained in $23(60.52 \%)$ of 38 cell blocks by ColB method while CS showed diagnostic material in 30 (78.94\%) of these cases. Diagnostic material by CB obtained in $23 / 38(60.52 \%)$ cases by ColB technique and $20 / 43(46.51 \%$ ) cases by PT technique was comparable to the study done by Vinayakmurthy et al. ${ }^{10}$ However Nathan et $\mathrm{al}^{11}$ obtained much better results as seen in the Table 5 below. The percentage of diagnostic CBs by ColB method was more as compared to the percentage of diagnostic $\mathrm{CBs}$ by PT method, however, as the diagnostic FNAs obtained in the cases in which CB was made by PT was also low, we are unable to reach a conclusion as to whether Col B definitely gives more diagnostic CBs than PT.

In our study, cellularity, use of ancillary test, recovery of cell clusters, preservation of morphology and the overall score for quality of cell block were similar for both techniques. However, in a study by Balassanian et al, ${ }^{9} \mathrm{ColB}$ technique was better than the other two techniques, PT and histogel (HG), in every aspect i.e. preservation of the cytomorphology and architecture as well as capturing and concentrating far more material from the FNAB samples, including tissue fragments and the free-floating single cells. One reason for the significantly better preservation and cellularity on ColBthan by HG and PT techniques found by Balassanian et al. could be that they used normal saline as rinsing solution in HG and PT methods. ${ }^{9}$ In particular, rinsing the FNAB needle directly into saline appeared to lyse most of the cells. Consequently, the sections of the majority of the PT CB samples demonstrated mainly stripped nuclei and cytoplasmic fragments. ${ }^{9}$ Different methods of cell block preparation with the use of different rinsing solution and fixative have been reported. ${ }^{9,11,12}$ In our study, the solution used for rinsing the FNAC needle was 10\% neutral buffered formalin for both techniques. And we found that both of the method had very little difference in cytomorphology and preserving architecture within small tissue fragments. The fixative used in our study, i.e. formalin might be responsible for both of the method having a comparable cellularity, cytomorphology, recovery of cell clusters and possible use of ancillary tests. On the other hand, Mansur et al. found marked cellularity with the use of saline as rinsing solution for FNAC needle, while formalin showed artifactually crowded cells and the material scattered through the slide. ${ }^{13}$

However, ColB technique has some limitations. Collodion is highly flammable. Thus, the collodion should be stored in small volumes in a flame-proof cabinet and used with appropriate precautions. It is true that use of ColB technique seem to be quite difficult in preparation of tube enlined with collodion solution. But later on it is found the easy storage of the collodion-lined test tubes for up to a month by refrigerating the tubes after filling them with distilled water and covering the top with paraffin. Thus, the collodion-lined test tubes can be prepared in large batches beforehand and be ready to use when needed. ${ }^{9,14}$ In our experience, Plasma thromboplastin technique on the other hand, was found to be more easily performed because clot formation is clearer and easily collected in filter paper as compared to the ColB technique. The current study has not evaluated the cost associated with each cellblock procedure and a cost analysis study could be done in future.

\section{CONCLUSION}

Cell block by PT and ColB method are cost effective, useful adjunct to FNA for diagnosis of mass lesion. Among the various methods for cell block preparation PT and ColB were found to be similar with no significance difference in quality of cell block produced. However, both ColB technique and PT technique facilitates the better diagnosis when used along with CS and therefore should be used routinely along with all FNACs.

\section{Funding Support}

Fund required to conduct the study was provided by Institute 
of Medicine, Maharajgunj Medical Campus and TUTH.

\section{Conflict of Interest: None}

\section{REFERENCES}

1. Lever J, Trott P, Webb A. Fine needle aspiration cytology. J ClinPathol. 1985;38:1-11. Crossref

2. Abraham DKRP EK, Mani M KS, Jayalal KS. Manual of Cytology. In: Department of Pathology RCC, Trivandrum, editor. Ministry of Health and Family Welfare, Government of India. 2005. p. 1-44.

3. Naz S, Hashmi AA, khurshid A, Faridi N, Edhi MM, Kamal A, et al. Diagnostic role of fine needle aspiration cytology (FNAC) in the evaluation of salivary gland swelling: an institutional experience. BMC Res Notes. 2015;8:101. Crossref

4. Koss LGM, Myron R., editor. Koss' Diagnostic Cytology and Its Histopathologic Bases. In: Britt-Marie Ljung, editor. Techniques of Fine-Needle Aspiration, Smear Preparation, and Principles of Interpretation. Diagnostic Cytology of Organs; vol 2. 5th ed. New York, UK: Lippincott Williams \& Wilkins; 2006. p.1057-78.

5. Saqi A. The State of Cell Blocks and Ancillary Testing: Past, Present, and Future. Arch Pathol Lab Med. 2016;140:1318-22. Crossref

6. Kocjan G. FNAC technique and slide preparation. Fine Needle Aspiration Cytology: Diagnostic Principles and Dilemmas. 2006:733 .
7. Basnet S TO. Role of cell block preparation in neoplastic lesions. J Pathol Nep. 2012;12:272-6. $\underline{\text { Crossref }}$

8. Kalhor N, Wistuba II. Perfecting the Fine-Needle Aspirate Cell Block. Cancer Cytopathol. 2013;121:109-10. $\underline{\text { Crossref }}$

9. Balassanian R, Wool GD, Ono JC, et al. A superior method for cell block preparation for fine $\square$ needle aspiration biopsies. Cancer Cytopathol. 2016;124:508-18. Crossref

10. Vinayakamurthy S, Manoli N, Shivajirao P, Manjunath, Jothady S. Role of Cell Block in Guided FNAC of Abdominal Masses. J ClinDiagn Res. 2016;10:Ec01-5. Crossref

11. Nathan NA, Narayan E, Smith MM, Horn MJ. Cell Block CytologyImproved Preparation and Its Efficacy in Diagnostic Cytology. Am J ClinPathol. 2000;114:599-606. Crossref

12. Koss LGM, Myron R., editor. Koss' Diagnostic Cytology and Its Histopathologic Bases. In: Carol E. Bales, editor. Laboratory Techniques. Techniques in Diagnostic Cytology vol 3. 5th ed. New York, UK: Lippincott Williams \& Wilkins; 2006. p1570-633.

13. Masur DS, Kadadavar SS, Nadig DM. Cytomorphologic Comparison of Formalin Cellblocks and Plasma-thrombin Cellblock Preparations in Cytodiagnosis of Serous Effusions. Ind J Public Health Res Dev. 2016;7:9-13. Available from: file://C:/Users/Pranay\%20Raj\%20 $\mathrm{KC} /$ Downloads/mafiadoc.com_cytomorphologic-comparison-offormalin-cellblocks_5c157c9f097c4782038b456c.pdf

14. Bedrossian CFUK. Collodion Bag: A Cell Block Technique for Enhanced Cell Collection. Lab Med. 2016;24(2):94-6. 